\title{
Article \\ Disorders, Vulnerabilities and Resilience in the Supply Chain in Pandemic Times
}

\author{
Catarina Ferreira ${ }^{1}$, Catarina Cardoso ${ }^{1}$, Mariana Travassos ${ }^{1}$, Mariana Paiva ${ }^{1}$, Micaela Pestana ${ }^{1}$, João M. Lopes ${ }^{1,2} \mathbb{E}$ \\ and Márcio Oliveira $2,3, *$ (D) \\ 1 Miguel Torga Institute of Higher Education, Largo da Cruz de Celas n ${ }^{\circ}$ 1, 3000-132 Coimbra, Portugal;

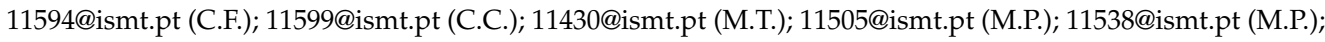 \\ joao.nuno.morais.lopes@ubi.pt (J.M.L.) \\ 2 NECE-Research Unit for Business Sciences, University of Beira Interior, R. Marquês de Ávila e Bolama, \\ 6201-001 Covilhã, Portugal \\ 3 Polytechnic Institute of Leiria, R. General Norton de Matos, Apartado 4133, 2411-901 Leiria, Portugal \\ * Correspondence: marcio.oliveira@ipleiria.pt
}

check for updates

Citation: Ferreira, C.; Cardoso, C.; Travassos, M.; Paiva, M.; Pestana, M.; Lopes, J.M.; Oliveira, M. Disorders, Vulnerabilities and Resilience in the Supply Chain in Pandemic Times. Logistics 2021, 5, 48. https://doi.org/ $10.3390 / \operatorname{logistics} 5030048$

Academic Editor: Robert Handfield

Received: 7 June 2021

Accepted: 1 July 2021

Published: 5 July 2021

Publisher's Note: MDPI stays neutral with regard to jurisdictional claims in published maps and institutional affiliations.

Copyright: (c) 2021 by the authors. Licensee MDPI, Basel, Switzerland. This article is an open access article distributed under the terms and conditions of the Creative Commons Attribution (CC BY) license (https:// creativecommons.org/licenses/by/ $4.0 /)$.

\begin{abstract}
The economic and social environment caused by the COVID-19 pandemic has brought additional pressure on supply chains because they now have more pressure to develop and adapt to a context of economic constraint. Delays in the supply chain can bring consequences such as the lack of food products by retailers, transporters and manufacturers. Thus, this study aims to examine the supply chain during the COVID-19 pandemic in small- and medium-sized food companies in the central region of Portugal, identifying potential problems and pointing out the respective solutions. For this purpose, the study uses a qualitative methodology through semi-structured interviews. It was found that small and medium-sized enterprises (SMEs) do not have a codified supply chain and that generally, these companies have a minimal budget, which requires a constant search for new suppliers that represent a reduction in costs. Moreover, most of the companies surveyed faced unexpected challenges, such as a lack of alternative suppliers. The present paper is original because it studies the supply chain in SMEs in the food sector during the COVID-19 pandemic, and it allows the ascertainment of practical suggestions for these companies to improve, as well as contributing to the clarification of the literature on the supply chain in times of crisis such as the current COVID-19 pandemic.
\end{abstract}

Keywords: supply chain disruptions; SARS-CoV-2/COVID-19 pandemic; small and medium food businesses; supply chain vulnerability and resilience

\section{Introduction}

A business model is understood as a structure composed of elements, interconnections and dynamics. The Complex Adaptive System (CAS) is one of the most advanced examples of systems theory. The addition of sophistication, flexibility and adaptation allows a CAS to reflect a business model [1]. A business model is composed of eight related resources, including resilience and adaptability, that lie at the boundaries of an organisation $[1,2]$. The phrase "adaptability causes uncertainty" is central to complex adaptive system (CAS) theory [3]. Stability within organisations through supply chains recognises the ability to withstand shocks in the form of severe events, and companies must establish constructive and reactive behaviour to acquire resilient capabilities to achieve this; that is, to be able to respond effectively to disasters that may occur [4]. The threat of supply disruptions must be considered in contemporary supply chain management. Supply chain delays usually arise with low probability, and however, even if they happen occasionally, they can bring severe consequences to companies [5]. Some researchers have resorted to using expected disruption cost (EDC) as a preparedness tool or metric [6].

Due to the COVID-19 pandemic, supply chains were forced to evolve and learn how to respond to this new society that presents dynamics of increased closure, isolation and 
restrictions on social and economic interactions. The restrictions imposed to prevent the spread of the virus directly affected the global economy and, consequently, the movement of goods. Pandemics and outbreaks, such as the COVID-19 virus, are possible causes of supply chain disruption [7]. As a result of this context, there have been negative impacts on world trade, with supply chains almost stopping their regular activity altogether. Among the disruptions that result from this, we can include delivery delays and labour shortages. Supply chain managers are aware that materials and commodities necessary to the business are in short supply worldwide. Supply disruptions should be included in current supply chain management and companies should plan their supply chains extensively [8]. They should also focus on keeping resilience balanced with efficiency and cost reduction to predict supply disruptions. The occurrences caused by the COVID-19 pandemic indicate a wide range of risks in the supply chain, where sudden instability affects its long-term development [7].

This study presents as a starting question "What are the most prevalent indicators of disruption, vulnerability and resilience in the supply chain in pandemic times" and focuses on deepening the knowledge about the supply chain when it is in a vulnerable position, either because of the effect of environmental or pandemic crises [9] or because it is in a situation of disruption. We also seek to understand how these companies can be resilient when they encounter these contexts. We analysed the supply chain of five companies in the food sector in Portugal.

Concerning the issues investigated in this work, the selection of suppliers and the ability of those responsible for considering their decision-making are factors considered conducive so that some kind of disruption occurs in the supply chain [5]. In the present study, it was possible to ascertain that supply chain vulnerability received little attention in the literature [10] and that a relationship of an environmental and anthropogenic nature, related to market volatility, prevails, since a notion is felt that a system will recover its initial state after the effect of the factors that affected it [4].

The main results are taken from this study point in the direction that the pandemic that we are going through has dramatically affected these companies' supply chains because they have suffered stock shortages due to the delayed arrival of products in this period. Finally, the companies have relatively low budgets, so they have to search for suppliers according to their budget, which ends up causing obstacles in creating long-term relationships.

However, there are limitations in this study, which prevent us from extracting the maximum knowledge from this subject. The current research was conducted in specific sectors and a particular context. For this very reason, we must limit ourselves to the unique circumstances and refrain from generalising the conclusions. Finally, we point out that the difficulty in defining the customer can be resolved by using a cause-effect relationship system [1].

This paper is structured as follows: It starts with the introduction, which is Section 1 of the article, to present the topic to be discussed. This is followed by a literature review in Section 2, which addresses the issue under study to familiarise the reader with it, address relevant concepts and explore theories. Section 3 presents the methodology followed in this study, and Section 4 presents and discusses the results. Finally, in Section 5, a brief conclusion is shown, where the main results obtained are explained.

\section{Literature Review}

\subsection{Complex Adaptive System Theory}

The term "complexity" originated from the Latin "complexus", which means multiple elements. However, some authors consider that the word comes from the Latin "plexus", which ends up meeting Tronca's understanding. This term in Latin means connected. Complexity science refers to a subset of all systems, which are called complex systems. The individual and causal study in these systems are described as trivial. That is, a broad perspective is needed to understand the unpredictability embedded in complex systems. 
To facilitate understanding of these systems, complexity science provides complex adaptive systems as support $[3,11,12]$.

A complex adaptive system is made up of several components that communicate with each other. When a mechanism evolves and communicates with the environment, its behaviour changes. The theory studies the characteristics of systems, such as selforganisation and adaptation [13-15]. This system is understood to be the suitable model to discuss the complexity present in social sciences today. It is understood as an efficient system that can structure its basic format by resorting to exchanging resources integrated into its environment. They are also able to shape these resources to support action. These systems are usually characterised by path dependency, disorganisation, contingency and adaptability $[3,15]$.

Complexity Theory is a modern way of interpreting current problems [12]. Complex adaptive system (CAS) theory was established in associated studies [3]. Edgar Morin is a vital complexity researcher today who proposed a change in the information model through paradigms of interknowledge in history, geography and law [12]. The author was the first to demonstrate the complexity procedure, starting from his model "Unity in diversity" (1973). This was followed by a Belgian scientist, Prigogine, who introduced "complexity science" [16].

In 1984, the Santa Fe Institute acquired the concept as a slogan and suggested that "adaptability creates complexity." In 1994, the same year that the institute celebrated its 10th anniversary, the development of the complex adaptive system theory was made official by Professor Holland [3]. Equilibrium and predictability are the exceptions, as contemporary research has shown through Complexity Theory. This theory justifies these nonlinear processes, allowing a deeper interpretation of order-disorder equilibrium [14,15].

Real-time planning is a form of complexity theory and allows for real-time predictions [15]. The purpose of CAS theory has broadened from the biological sciences to the social sciences due to its development. This theory is understood to be suitable for analysing decision-making mechanisms and the influence of the interaction of multiple participants [16]. Complexity Theory was referred to as a potential new concept in science [12].

In this theory, due to the relationships/interactions and the new information created by them, the concept of unpredictability appears [11]. As said before, the meaning of this theory focuses on the expression of "adaptability creates complexity," and it presents two levels: micro and macro. As for the micro-level, the individual and the environment can instruct each other using mutual interaction, while at the macro level, the behaviour taken by the subject impacts the environment, which is constantly changing, ultimately limiting the subject's behaviour [16]. After the 1960s, internal and external conditions became increasingly dynamic, putting enormous pressure on business, especially in strategy. Corporations then began to seek flexible, innovative and multi-skilled employees [15].

Wang, Dong, Zhang and Luo [16] drew upon the theory in question, using it as a basis for analysing the matter of low resilience regarding the management of adversity in community public health. These authors emphasise that this theory is applied as a support because of its ability to highlight the relationship between individuals and the environment to improve adaptability to the environment. In the same study, it is suggested to institute a model for community multicultural relationship resilience using the complex adaptive system theory to extend the level of resilience [16]. Some studies aggregate this theory together with fashion [12] and others that refer, in their themes, the theory involved with different companies, applying it to the perspectives of their organisational environment [15].

\subsection{Business Supply Chain Disruptions}

According to the authors, Fahimnia, et al. [17], supply chain managers are subjected to new challenges, such as building a supply chain network that is effective, efficient and resilient enough to overcome disruptions. However, at the same time, it must be sustainable [18]. These disruptions can be caused by natural phenomena such as earthquakes, 
tsunamis and bad weather, or by the hand of humans [19]. For this reason, the authors also mentioned that supply chain groups tend to deviate from their sustainability purposes while dealing with unpredictable disruption [6].

Authors Sureeyatanapas, Waleekhajornlert, Arunyanart and Niyamosoth [5] agreed that disruptions regarding supply disruptions are expanding among companies. However, with the pandemic that the world is currently experiencing, supply chains have been forced to adapt and adjust to this new closed world. Consequently, a worldwide shortage of essential products and goods has occurred [8]. These events forced companies to change their management and logic in supply chains, alerting them to the changes that needed to be applied if disruptive events of the same kind happened again [8]. Some authors suggest companies perform extensive mapping of their supply chains so that it is possible to predict and anticipate supply-side disruptions $[8,20]$.

Thus, the threat of supply disruptions must be considered in modern supply chain management [21]. Suppose the danger of disruption is related to the supplier choice issue. In that case, it will be unwise to assume that complete data about all the criteria or the complete understanding of the decision-maker regarding the problem are available. The occurrences of disruptive phenomena usually occur with low probability but with high intensity and can be seen as ambiguities concerning the supply chain system [5].

Some authors resorted to using EDC (expected disruption cost) as a metric for planning a resilient supply chain network [22]. For example, suppose there is any supplier that is susceptible to outages. In that case, the responsible individual may choose to go for another one without considering the sustainability factor, i.e., decreasing the risk of outages [6].

Even though the feasibility of disruptions is hard to assess, Lim, et al. [23] concluded that devaluing the probability of disruptions comes out to be more risky/dangerous than overestimating the chance (Mari et al., 2014). The way to maintain a handle on these costs of disruptions, supply chain costs and others is to perform an approach grounded in multi-objective goal planning [6].

\subsection{Vulnerability in the Supply Chain}

In our study, we considered that vulnerability is a variable formed on the outside, and through the size of an impact, or even some kind of damage, it can determine the risk [10]. Associated with the supply chain, it aims to demonstrate the extent to which it is exposed to a disruptive event [24]. Therefore, the vulnerability in the supply chain can be seen when a value movement, if it is exogenous, allows flexibility and can determine the value of product delay [25] and in a product or even during an information-sharing process. However, we can also find it in intangible assets (hardware, software, infrastructure and relations with other companies), as well as in the environment (political issues, such as economic, social, or technological [9].

The risk of inherent invulnerability is found when an interruption is determined. This risk and the ability to withstand a shock and strengthen the supply chain are characteristics by which vulnerability is defined [10]. In this regard, it was necessary to analyse the components (vulnerability and risk) in the case of a disruption. Thus, a graph theory was defined [26].

After the analysis of the components [26], some practices seek to combat vulnerability in the supply chain, such as: proactively manage the risks that the supply chain is subject to, and for this entrepreneurs will need to have methods to identify and measure the possible vulnerabilities, so that they can change factors that coincide with the expected compensation, in terms of risk-reward $[27,28]$. In a study conducted on the Toyota company, it was clarified that vulnerability might be lower, upon an interruption, if a node degree level (supply chain, in which the network has nodes) is associated with a power law in a supply network structure [26,29].

The concept of resilience, identified as an alternative to control some risks, was studied and worked on in the literature, unlike the little-discussed vulnerability. They only learn to 
consider and quantify its index and guide the processes involved in optimising the value related to revenue $[10,30]$.

\subsection{Resilience in the Supply Chain}

The word resilience originally comes from materials science. This refers to the ability of a system to recover its initial state after undergoing an elastic deformation without any changes in its nature [31]. Due to market instability, environmental problems and manufactured disasters, the importance of incorporating this concept was emphasised in the operations management scenario [32]. In operations management, resilience is defined as organisational capabilities to face immediate changes in the environment with proactive and reactive actions $[33,34]$.

The first broad study on supply chain resilience began in the UK following transport disruptions due to fuel protests in 2000 and the foot and mouth disease outbreak in early 2001 [35]. The study explored the UK industrial knowledge base on supply chain vulnerabilities and found that: supply chain vulnerability is a major business issue, there is little research on supply chain vulnerability, awareness of the issue is weak and a methodology is needed to manage supply chain vulnerability [35].

Based on this empirical research, Christopher and Peck [36] developed an initial framework for a resilient supply chain. These authors stated that supply chain resilience could be created according to four key principles: (1) resilience can be built into a system before a disruption, (2) a high level of collaboration is required to identify and manage risks, (3) agility is essential to react quickly to unforeseen events and (4) risk management culture is a necessity. Characteristics such as agility, availability, efficiency, flexibility, redundancy, speed and visibility were treated as secondary factors [37].

Given that almost every supply chain faces disruptions of severity and various types, it is important to be prepared for any future disruptive event [38,39]. In a way that allows companies to respond efficiently and effectively and therefore become less vulnerable to disruptions [40]. Therefore, resilience within organisations and across supply chains recognises the ability to absorb shocks in the form of extreme events and the adaptive capacity to adjust to new circumstances and is then recognised as a response capability for a firm's performance as well as a key dimension for a firm's survival [4,41,42].

However, not all risks and impacts are predictable. In this way, if an interruption in the flow of goods or information occurs, there must be an immediate and effective response to minimise losses $[36,43,44]$. In this sense, to obtain adaptive capabilities to better respond to disasters, companies must develop proactive and reactive actions to overcome the impacts and remain competitive [42].

\subsection{The Relationship between Adaptive System Complexity and Supply Chain Disruption, Vulnerability and Resilience}

Supply chain resilience is related to disruption, vulnerability and the balance of recovery and resilience strategies [45-47].

Although several scholars have framed the collection of elements that make up a business model as a system [2], unfortunately, general system theory and system dynamics cannot model the true complexity of the business. That said, related constructs inevitably lack the attributes needed to explain this complexity and dynamism [1].

One of the most evolved forms of systems theory-the Complex Resilient Adaptive System (RCAS) - is proactively employed to prescribe the key considerations that must be addressed in a business model [1].

The introduction of complexity, resilience and adaptation allows an RCAS to represent a business model more accurately than general system theory, with strong alignment between the characterisation of an RCAS and the characteristics of a business environment [1]. Afuah and Tucci [2] defined a business model as a "system made of components, links between components, and dynamics". Andersson, et al. [48] also considered business models in terms of agents, activities and resource exchanges between them, employing goal modelling from the business and information systems school of thought [1]. Itami and 
Nishino [49] believed that a business model comprises two elements: a business system and a profit model [1]. Baden-Fuller and Haefliger [50] defined the business model as a system involving cause and effect relationships that identify who the customer is, engage with their needs, deliver satisfaction and monetise value [1]. Gassmann, et al. [51] viewed the business model as a system, adopting a systems lens as a theoretical framework to articulate how business model evolution occurs.

The systems theory has framed the notion of resilience as, for example, in resilient infrastructure systems, the ability of an entity or system to return to a normal condition after the occurrence of an event that interrupts its state [52], or perhaps more strategically, to the measure of a system and the ability to absorb ongoing, unpredictable change and still maintain its vital functions [1].

Finally, we consider in this study that a business model is a complex, resilient, adaptive system (RCAS) that is structured in the form of eight interconnected elementary functions, including resilience and adaptation, positioned within the boundaries of an enterprise, which operate in a feedback loop to create and manage value exchange [1].

\section{Methodology}

This qualitative study analyses the supply chain in vulnerable interruption situations resulting from the current pandemic context. It also analyses these companies' disruption, vulnerability and resilience to overcome the difficulties arising from this context within their supply chains. A qualitative study was suitable for the present research because observation in natural environments, in this case, allows interpretation and research phenomena such as the functioning of supply chains to understand the processes in the daily life of these companies. Thus, the qualitative method was suitable for this study. It requires a lot of effort and time to analyse the data collected through the interviews because it is a complex phenomenon [53-55].

The present study is a multiple case study where we applied semi-structured interviews previously used by Yaroson, Breen, Hou and Sowter [47]. The interviews lasted an average of $40 \mathrm{~min}$. The type of sampling is non-probability by convenience because, for the study, we only considered companies in the central region of Portugal, which is a low-density region, as well as food companies. The strategy used for this study was cross-analysis, taking into account that it is guided by variables with characteristics that do not have quantitative values $[55,56]$.

The companies in this study are SMEs. This aspect is reflected in the data provided by the Pordata platform, as it shows us a higher value, in terms of size, for SMEs than for large companies in Portugal (Table 1). However, the sectors, namely agriculture, manufacturing and restaurants, where these companies are included are in the group of sectors with larger sizes compared to the other sectors. Companies operating in these sectors suffered severe constraints at the various levels of their operations or logistics when the COVID-19 pandemic emerged and its social and economic consequences took hold. The lack of availability of food goods by retailers, transporters and manufacturers has brought consequences such as delays in the supply chain, with almost immediate practical consequences on quality of life and access to consumer goods by the general population, by that the selection of these SMEs becomes even more relevant.

Table 1. Size of companies and weight of corporations and sole proprietorships in Portugal.

\begin{tabular}{ccc}
\hline & Large Enterprises & SME \\
\hline 2019 & 1357 & $1,333,649$ \\
\hline 2019 & Companies & Individuals \\
\hline Source: https://www.pordata.pt, accessed on 26 May 2021. & 887,735 \\
\hline
\end{tabular}

Source: https://www.pordata.pt, accessed on 26 May 2021. 
Table 2 presents the data from the companies under study.

Table 2. Companies Data.

\begin{tabular}{cccccc}
\hline & Company A & Company B & Company C & Company D & Company E \\
\hline $\begin{array}{c}\text { Date and Time of } \\
\text { Interview }\end{array}$ & $\begin{array}{c}29 \text { March 2021 } \\
14: 00 \mathrm{~h}\end{array}$ & $\begin{array}{c}4 \text { April 2021 } \\
21: 02 \mathrm{~h}\end{array}$ & $\begin{array}{c}27 \text { March 2021 } \\
16: 37 \mathrm{~h}\end{array}$ & $\begin{array}{c}30 \mathrm{March} 2021 \\
15: 00 \mathrm{~h}\end{array}$ & $\begin{array}{c}05 \mathrm{April} \text { 2021 } \\
10: 00 \mathrm{~h}\end{array}$ \\
\hline Interviewee & CEO & CEO & CEO & CEO & CEO \\
\hline Type of Company & Unipessoal Limited & $\begin{array}{c}\text { Private Limited } \\
\text { Company }\end{array}$ & $\begin{array}{c}\text { Private Limited } \\
\text { Company }\end{array}$ & $\begin{array}{c}\text { Private Limited } \\
\text { Company }\end{array}$ & $\begin{array}{c}\text { Private Limited } \\
\text { Company }\end{array}$ \\
\hline $\begin{array}{c}\text { Area of Responsibility } \\
\text { Years of Experience of the } \\
\text { interviewee }\end{array}$ & Food & Food /Farming & Food & Food & Food \\
\hline Invoicing Volume 2020 & EUR 500,000 & EUR 400,000 & EUR 2,000,000 & EUR 6,278,000 & EUR 1,000,000 \\
\hline
\end{tabular}

\section{Results and Discussion of the Results}

Supply chain disruptions in companies can happen due to environmental factors and human nature [6]. That said, the supply chain, after a disruption, becomes vulnerable [9] and thus needs to recover from these situations, so it needs to be resilient [4].

\subsection{Supply Chain Disruptions}

In Table 3, we can see the results in the theme of supply chain disruptions. The delay in these companies is mostly due to the lack of supply of a food product by suppliers, transporters and producers (C, D, E); the closing of the borders between France and England due to Brexit (in the case of Company B); and due to epidemiological issues (Company A, there was a lack of important protein for the confection of the final product). This delay takes at least five days to three weeks (Company A, B, D, E); only Company C mentions that the product delay happens intermittently due to pandemic issues. In this study, the COVID-19 pandemic was identified as one of the main obstacles, and in the literature, it is also possible to verify its impact on product shortages $[8,57,58]$.

Table 3. Synthesis of results of supply chain disruptions.

\begin{tabular}{|c|c|c|c|c|c|c|c|}
\hline & $\begin{array}{l}\text { Timing of } \\
\text { Product } \\
\text { Supply } \\
\text { Delay }\end{array}$ & $\begin{array}{c}\text { Duration and } \\
\text { Reason for } \\
\text { the Delay }\end{array}$ & $\begin{array}{l}\text { The Quickness of the } \\
\text { Perception of the } \\
\text { Interruption/the } \\
\text { Reason That Caused It }\end{array}$ & $\begin{array}{c}\text { Alert } \\
\text { Metrics in a } \\
\text { Disruptive } \\
\text { Event }\end{array}$ & $\begin{array}{l}\text { Quick } \\
\text { Perception of } \\
\text { the Impact of } \\
\text { the Interruption }\end{array}$ & $\begin{array}{l}\text { Perceived } \\
\text { Impact on } \\
\text { Areas of the } \\
\text { Supply Chain }\end{array}$ & $\begin{array}{c}\text { Barrier } \\
\text { Encountered } \\
\text { during the } \\
\text { Interruption }\end{array}$ \\
\hline Company A & $\begin{array}{l}\text { Lack of } \\
\text { protein }\end{array}$ & $\begin{array}{l}\text { - } 3 \text { weeks } \\
\text { - COVID-19 }\end{array}$ & 2 days & $\begin{array}{c}\text { Early } \\
\text { warning } \\
\text { from the } \\
\text { wholesaler }\end{array}$ & Instantaneous & $\begin{array}{c}\text { Raw } \\
\text { materials } \\
\text { sales area }\end{array}$ & $\begin{array}{c}\text { Lack of } \\
\text { suppliers of } \\
\text { the same raw } \\
\text { material }\end{array}$ \\
\hline Company B & $\begin{array}{l}\text { Fresh } \\
\text { product } \\
\text { delay }\end{array}$ & $\begin{array}{l}\text { - } 2 \text { weeks } \\
\text { - Brexit }\end{array}$ & - Immediately & $\begin{array}{l}\text { No metrics } \\
\text { of any kind }\end{array}$ & 1 day & Sales area & $\begin{array}{l}\text { Demand } \\
\text { from } \\
\text { customers, } \\
\text { other } \\
\text { suppliers }\end{array}$ \\
\hline Company C & $\begin{array}{c}\text { Bovine } \\
\text { animal } \\
\text { protein delay }\end{array}$ & $\begin{array}{l}\text { - Intermittent } \\
\text { delay } \\
\text { - Bovine } \\
\text { spongiform en- } \\
\text { cephalopathy } \\
\text { disease }\end{array}$ & - Immediately & $\begin{array}{c}\text { No metrics } \\
\text { at all }\end{array}$ & Immediately & Sales area & $\begin{array}{l}\text { Fear in beef } \\
\text { consump- } \\
\text { tion }\end{array}$ \\
\hline Company D & $\begin{array}{l}\text { Vegetable } \\
\text { product } \\
\text { delays }\end{array}$ & $\begin{array}{c}\text { - } 5 \text { days } \\
\text { - Product } \\
\text { production } \\
\text { delay }\end{array}$ & 2 days & $\begin{array}{l}\text { Producer } \\
\text { early } \\
\text { warning }\end{array}$ & Immediately & $\begin{array}{c}\text { Operating } \\
\text { area }\end{array}$ & $\begin{array}{l}\text { Reaching } \\
\text { alternative } \\
\text { producers }\end{array}$ \\
\hline Company E & $\begin{array}{l}\text { Flour } \\
\text { product } \\
\text { delay }\end{array}$ & $\begin{array}{c}\text { - } 5 \text { days } \\
\text { - Delay in flour } \\
\text { transportation }\end{array}$ & - Immediately & $\begin{array}{l}\text { Supplier } \\
\text { early } \\
\text { warning }\end{array}$ & At the time & $\begin{array}{c}\text { Operating } \\
\text { area }\end{array}$ & $\begin{array}{l}\text { Finding a } \\
\text { flour } \\
\text { supplier }\end{array}$ \\
\hline
\end{tabular}


Moreover, in Table 3, it is possible to verify that almost all companies have early warnings as a metric. Only Company $\mathrm{C}$ mentions not having any metrics. Companies are discerning the interruption's impact; only Company B takes a day to realise it. They mostly perceive the impact on the sales areas, and Companies D and E refer to the operational area. In the literature, it is also possible to verify metrics, namely the expected cost of interruption, regarding chain planning [6] of risk detection visibility and learning [59,60].

The barriers found in Table 3 for the resolution of the interruption are the lack of alternative suppliers that ensure the same quality (Company A, D, E): one company refers to the fear of not consuming the products they sell (Company $\mathrm{C}$ ) and Company B refers to the search for new suppliers by customers, which we can see is that it does not allow companies to have close and lasting relationships with suppliers, and this aspect would be very beneficial since it could produce high-quality products [58,61].

The supply chain can be exposed to some disruptive situation, creating a certain vulnerability [24], which can be countered through practices, such as proactive management [28].

\subsection{Supply Chain Vulnerabilities}

Table 4 addresses the theme of supply chain vulnerability, companies characterise their products as perishable products, with possibilities for innovation, as in the example of Company A, which intends to innovate in faster machines to decrease the time of confection of the final product and allows the competitiveness of the company to be increased [62,63].

Moreover, in Table 4, regarding the supply chain, for all companies present, there is almost always the same record of a process initiated by pre-defined contracts with suppliers, then the products are delivered by a carrier, after receipt they are stored, some are processed, others resold until they reach the final consumer. The companies provide directly to the final consumer, and only one delivers by own transport to customers, who promptly sell to the final consumer. The literature also mentioned, in addition to production, optimising maintenance and control to decrease costs [64].

Three companies present amplifying resources; in Table 4, A, D and E, refer to the product shelf life as a resource that amplifies the disruptive activities. Company A still refers to the margin of error of the human factor in the confection of the product, and companies $B$ and $C$ refer to not having amplifying resources. The issue of amplifying stock variation can bring instability, resulting from supply chain dynamics [65].

Four companies report that communication, embedded in management, with the other supply chain members is an asset for the company in a disruption. Only Company D does not consider that its management decision affects a disorder. This internal communication issue is also seen in the literature as a competitive advantage [66].

From both the role of suppliers in a disruptive activity and their role at the time of that activity, only one company stated that suppliers have a function, and that function is to deliver the products needed to achieve that innovation. They exemplified the incremental innovation of the sweet "fradinhas", in which they had to ask suppliers for the products needed for its confection, and again allows a competitive advantage [62,63].

Finally, all the companies refer that the regulatory bodies supervise and inspect the company to provide safety to the final consumers. Two of the companies refer to the ASAE. One refers to GRASP, and one refers to the state veterinarians that supervise the process. Only one company presents a regulatory body that prepares the company to avoid management deficiencies, such as the training provided by the HCCP. It was verified in this study that regulatory bodies serve to eliminate and regulate certain deficiencies in the supply chain, that is, to reduce risks to human health, thus these regulated sectors are entitled to certification to prevent counterfeiting [67].

In this case, the supply chain has to be able to overcome disruptions caused by natural phenomena [6] that the same, created outside [10], cause vulnerability in it. Systems have to recover from these phenomena to stabilise in the initial situation [4]. 
Table 4. Summary of results of supply chain vulnerabilities.

\begin{tabular}{|c|c|c|c|c|c|c|c|}
\hline & $\begin{array}{l}\text { Product Characteristics } \\
\text { and Whether It Amplifies } \\
\text { Disruptive Activity }\end{array}$ & Supply Chain & $\begin{array}{l}\text { Amplifier Feature } \\
\text { for Disruptive } \\
\text { Activities }\end{array}$ & $\begin{array}{l}\text { Role of Suppliers in } \\
\text { Disruptive Activity }\end{array}$ & Role of Suppliers & $\begin{array}{l}\text { Effect of Management } \\
\text { Decisions during an } \\
\text { Interruption }\end{array}$ & $\begin{array}{c}\text { Role of Regulatory } \\
\text { Bodies }\end{array}$ \\
\hline Company A & $\begin{array}{l}\text { - Product confectioned } \\
\text { moments before delivery. } \\
\text { - Willingness to innovate in } \\
\text { terms of machinery, to } \\
\text { shorten the cooking time }\end{array}$ & $\begin{array}{l}\text { - Producers or suppliers contact the } \\
\text { company } \\
\text { - Delivery deadlines established } \\
\text { - Delivery by carriers } \\
\text { - Storage of raw material } \\
\text { - Transformation of the raw material } \\
\text { into the final product }\end{array}$ & $\begin{array}{l}\text { - Expiration of } \\
\text { products } \\
\text { - Higher margin of } \\
\text { error since the final } \\
\text { product is executed } \\
\text { by labour }\end{array}$ & $\begin{array}{l}\text { Does not have a role in } \\
\text { disruptive activity. } \\
\text { Since the products are } \\
\text { raw materials, they } \\
\text { cannot innovate }\end{array}$ & Does not have a role & $\begin{array}{l}\text { Joint communication } \\
\text { facilitates the resolution } \\
\text { of the disruptive } \\
\text { activity }\end{array}$ & $\begin{array}{l}\text { Supervision of frauds } \\
\text { and management } \\
\text { deficiencies (ASAE) }\end{array}$ \\
\hline Company C & $\begin{array}{l}\text { Products that require } \\
\text { refrigeration and are open } \\
\text { to innovations }\end{array}$ & $\begin{array}{l}\text { - Daily orders } \\
\text { - Receiving live cattle at transporters } \\
\text { - Storage of cattle } \\
\text { - Slaughtering and processing } \\
\text { of livestock } \\
\text { - Own transport to customers } \\
\text { - At customers' locations, as butchers } \\
\text { are sold to the final consumer }\end{array}$ & $\begin{array}{l}\text { There are no } \\
\text { magnifying } \\
\text { resources. }\end{array}$ & $\begin{array}{l}\text { Suppliers do not } \\
\text { have a role }\end{array}$ & $\begin{array}{l}\text { They do not have } \\
\text { any role. }\end{array}$ & $\begin{array}{l}\text { Communication with all } \\
\text { agencies in the } \\
\text { supply chain }\end{array}$ & $\begin{array}{l}\text { - State Veterinarians, } \\
\text { guarantee the legality of } \\
\text { the process of collection } \\
\text { and slaughter of } \\
\text { animals; } \\
\text { - ASAE supervises and } \\
\text { inspects the company }\end{array}$ \\
\hline Company D & $\begin{array}{l}\text { Perishable horticultural and } \\
\text { fruit products, with the } \\
\text { possibility of innovation }\end{array}$ & $\begin{array}{l}\text { - The company contacts the producers } \\
\text { - Reception of products } \\
\text { - Storage of fruit and } \\
\text { vegetable products } \\
\text { - Sale of the products to wholesalers } \\
\text { and final consumers }\end{array}$ & $\begin{array}{l}\text { Delivery time, since } \\
\text { they are perishable } \\
\text { products, if they are } \\
\text { not delivered on the } \\
\text { due date, the } \\
\text { products spoil }\end{array}$ & Does not have a role & $\begin{array}{l}\text { Does not } \\
\text { have a function }\end{array}$ & $\begin{array}{l}\text { The company believes } \\
\text { that its management } \\
\text { decisions do not affect } \\
\text { in the event of a } \\
\text { disruption }\end{array}$ & $\begin{array}{l}\text { Ensure the safety of } \\
\text { public health }\end{array}$ \\
\hline Company E & $\begin{array}{l}\text { Products made in-house, } \\
\text { with the possibility to } \\
\text { innovate }\end{array}$ & $\begin{array}{l}\text { - Producers (who make the products) } \\
\text { - Suppliers who deliver the products to } \\
\text { the bakery through their transporters } \\
\text { - They store the products } \\
\text { - Some are processed, and others resold } \\
\text { - Delivery to the final consumer }\end{array}$ & $\begin{array}{l}\text { - Conservation; } \\
\text { - Expiration date } \\
\text { - Mismanagement }\end{array}$ & $\begin{array}{l}\text { The role is to deliver the } \\
\text { feeds needed to make } \\
\text { this innovation happen }\end{array}$ & $\begin{array}{l}\text { At the time of the } \\
\text { innovation of the } \\
\text { fradinhas (new cake } \\
\text { made in the } \\
\text { company), they had } \\
\text { to deliver flour }\end{array}$ & $\begin{array}{l}\text { Good connections with } \\
\text { employees and } \\
\text { suppliers }\end{array}$ & $\begin{array}{l}\text { Ensure the conservation } \\
\text { of products so as not to } \\
\text { affect the well-being of } \\
\text { final consumers }\end{array}$ \\
\hline
\end{tabular}




\subsection{Resilience in the Supply Chain}

The resilience in the supply chain, explicit in Table 5, goes through strategies to prepare and respond to an interruption. All companies report having strategies, where communication and alternative producers or suppliers stand out, where three companies report that it affects customer satisfaction and two companies report optimising time [64,66].

The five companies all highlight resources and process enablers during this event, namely alternative products and suppliers or using products from companies in areas near the companies' location. Four companies, A, B, C and D, have meetings to obtain information from stakeholders, and three companies, B, C, D and E, still incorporate daily phone calls. All companies have information-sharing activities with the other companies [66]. Regarding the competitive position, two of the companies, A and B, intend to ensure market share. Three refer to differentiation in the reduction of time in the preparation of dishes, another company refers to the good management of stock, and lastly, one company refers to the diversification of products $[62,63]$.

All of the companies present the ability to obtain products at the time of disruptive activity, as well as available suppliers. Lastly, obstacles, mainly the COVID-19 pandemic, were referred to by three companies. Company B referred to Brexit and the difficulty in delivering by deadlines since the borders were closed during that time. In a contradictory way, the literature states that the European Union loses little with these types of situations [68]. Finally, four companies present ways to improve the supply chain in disruptive activity through greater knowledge of innovative processes or products by suppliers. Only Company E refers that there are no ways to improve. The operational part appears in the literature as the area in the supply chain that needs improvement [69]. 
Table 5. Summary of results of resilience in the supply chain.

\begin{tabular}{|c|c|c|c|c|c|c|c|c|c|}
\hline & $\begin{array}{l}\text { Strategies for } \\
\text { Responding to } \\
\text { Interruptions }\end{array}$ & $\begin{array}{l}\text { Resources that } \\
\text { Support the } \\
\text { Disruptive Event }\end{array}$ & $\begin{array}{l}\text { Effect of } \\
\text { Strategies on } \\
\text { Interruption }\end{array}$ & $\begin{array}{l}\text { the Competitive } \\
\text { Position of the } \\
\text { Company }\end{array}$ & $\begin{array}{l}\text { Process of Obtaining } \\
\text { Information from } \\
\text { Stakeholders }\end{array}$ & $\begin{array}{l}\text { Ability to Obtain } \\
\text { Product over a } \\
\text { Disruptive Activity }\end{array}$ & $\begin{array}{l}\text { Available } \\
\text { Suppliers }\end{array}$ & Obstacles & $\begin{array}{l}\text { How to Better } \\
\text { Prepare a } \\
\text { Supply Chain }\end{array}$ \\
\hline Company A & $\begin{array}{l}\text { - Identical } \\
\text { products } \\
\text { - Substitution with } \\
\text { another product }\end{array}$ & $\begin{array}{l}\text { Resort to } \\
\text { companies in the } \\
\text { company's area }\end{array}$ & Time optimisation & $\begin{array}{l}\text { Product quality at } \\
\text { a low price, in a } \\
\text { short time of } \\
\text { production }\end{array}$ & $\begin{array}{l}\text { - Individual Meetings } \\
\text { - Collective meetings }\end{array}$ & $\begin{array}{l}\text { - Alternative Products } \\
\text { - Contact with } \\
\text { suppliers }\end{array}$ & $\begin{array}{l}\text { Yes, since they are } \\
\text { large suppliers, } \\
\text { that is, with great } \\
\text { capacity }\end{array}$ & $\begin{array}{l}\text { Increase in } \\
\text { raw materials } \\
\text { due to } \\
\text { COVID-19 }\end{array}$ & $\begin{array}{l}\text { Increased supplier } \\
\text { communication } \\
\text { about innovative } \\
\text { processes }\end{array}$ \\
\hline Company B & $\begin{array}{l}\text { - Remodeling of } \\
\text { the delivery } \\
\text { procedure } \\
\text { - Identical } \\
\text { products }\end{array}$ & $\begin{array}{l}\text { Daily contact with } \\
\text { intermediaries }\end{array}$ & $\begin{array}{l}\text { Satisfied } \\
\text { customers }\end{array}$ & $\begin{array}{l}\text { Securing market } \\
\text { share }\end{array}$ & $\begin{array}{l}\text { - Weekly meetings } \\
\text { - Daily phone calls }\end{array}$ & $\begin{array}{l}\text { Regular contacts and } \\
\text { good relationships } \\
\text { with suppliers to } \\
\text { obtain the product }\end{array}$ & $\begin{array}{l}\text { Yes. Some } \\
\text { suppliers are } \\
\text { always able to } \\
\text { deliver } \\
\text { immediately }\end{array}$ & $\begin{array}{l}\text { Brexit, with } \\
\text { the closing of } \\
\text { the borders } \\
\text { between } \\
\text { France and } \\
\text { England }\end{array}$ & $\begin{array}{l}\text { Increased supplier } \\
\text { knowledge of } \\
\text { innovative } \\
\text { planting } \\
\text { procedures } \\
\text { horticultural and } \\
\text { fruit treatment }\end{array}$ \\
\hline Company C & $\begin{array}{l}\text { - Communications } \\
\text { - Alternative } \\
\text { suppliers }\end{array}$ & $\begin{array}{l}\text { Alternative } \\
\text { suppliers }\end{array}$ & $\begin{array}{l}\text { - Optimise time } \\
\text { - Achievement of } \\
\text { stipulated } \\
\text { deadlines }\end{array}$ & $\begin{array}{l}\text { Assure customers } \\
\text { by supplier } \\
\text { alternatives }\end{array}$ & $\begin{array}{l}\text { Meetings with } \\
\text { stakeholders }\end{array}$ & $\begin{array}{l}\text { A good relationship } \\
\text { with suppliers }\end{array}$ & $\begin{array}{l}\text { Yes, depending on } \\
\text { the product }\end{array}$ & COVID-19 & $\begin{array}{l}\text { Communication } \\
\text { with stakeholders } \\
\text { to seek innovative } \\
\text { ideas either for } \\
\text { products or } \\
\text { processes }\end{array}$ \\
\hline Company E & Have stock & $\begin{array}{l}\text { The company is } \\
\text { branched into four } \\
\text { establishments, so } \\
\text { they supply each } \\
\text { other in this case }\end{array}$ & $\begin{array}{l}\text { The decreased risk } \\
\text { with customer } \\
\text { satisfaction }\end{array}$ & $\begin{array}{l}\text { The competitive } \\
\text { position of } \\
\text { differentiation, by } \\
\text { the issue of never } \\
\text { lacking product }\end{array}$ & $\begin{array}{l}\text { - Phone calls when } \\
\text { necessary } \\
\text { - Quarterly meetings }\end{array}$ & Product alternative & $\begin{array}{l}\text { Diversified and } \\
\text { available suppliers }\end{array}$ & COVID-19 & $\begin{array}{l}\text { With effective } \\
\text { stakeholder } \\
\text { communication, } \\
\text { we can access } \\
\text { innovative ideas } \\
\text { that can cover the } \\
\text { various areas }\end{array}$ \\
\hline
\end{tabular}




\section{Conclusions}

The present study examined the supply chain in specific companies in the food sector during the COVID-19 pandemic, identified potential problems and pointed out solutions to those problems. The study aims to address the functioning of the supply chain, to integrate the components of vulnerability and resilience, taking into account that good management of the supply chain of companies can increase their competitive advantage.

The main conclusion that can be highlighted is that the interviewed companies are mostly companies that belong to SMEs, which makes them not have a formalised supply chain, unlike large companies, and is later reflected in the lack of metrics. It was also evident that the COVID-19 pandemic affected the companies' supply chains in a harmful way since several delays in the supply of products during that period. In addition to all this, the fact that these companies have smaller budgets forces them to look for solutions, such as constantly seeking low-cost suppliers and maintaining quality, which consequently does not allow the company to maintain long-term relationships with them. Finally, it is also possible to conclude that most companies under study have the same difficulties in solving the interruptions, i.e., the lack of alternative suppliers that can guarantee the same quality in the products.

All companies present several aspects that can be improved. Among them is that many of them identify that suppliers have no function or role in an activity seen as disruptive. In this way, companies could improve this aspect by seeking innovative solutions for their products from their suppliers. They can also improve their supply chain by identifying new suppliers. It would be important to unify all the management in one system because it is important to choose an efficient management system to facilitate the visualisation of each step of the process and improve its supply chain. Another aspect that can always be improved is the greatest possible integration of the whole team involved in the chain. With aligned teamwork, it is possible to reduce operational costs, improve process productivity and manage stock to benefit the entire supply chain. It could be good for companies to analyse previous results (their history) better since this action enables managers to prepare for unforeseen or future failures.

The study's practical implications would be very interesting and valuable for companies to opt for new practices, such as establishing new partnerships. A good example would be to establish partnerships with companies that deliver orders from a smartphone application. These applications usually deliver food, pharmacy products, or even supermarket products. It is an easy way to connect sellers and consumers through couriers who drive the order to the consumer's desired location. Since the companies in this study are all food companies, it would be an added value. From these applications, the companies would reach a larger number of people and consequently make more sales and increase their turnover. SMEs and their employees must adapt to the use of information technology tools and enjoy the advantages of working in a network and a virtual environment. There must be a better use of digital platforms available for this purpose and that best suit their business. These tools should favour the facilitation of communication with customers, cost reduction and business profitability.

Concerning theoretical implications, it can be said that there is very little literature on supply chains in SMEs. This study is important to contribute to the literature of supply chains in SMEs in times of pandemic or crisis. This study compares several companies in the food sector and sellers of perishable products, providing additional value, given the existing scarcity of studies among several companies.

It is also important to mention that this study is original because few studies on this theme applied to SMEs and in the Portuguese context. We highlight that they are all food sector companies, which allows us to make certain comparisons between the companies and understand certain differences between them and their respective supply chains.

Finally, in this study, we present some limitations and indicate possible recommendations for future lines of research. There are always limitations in the study that prevent us from obtaining the maximum and highest quality information possible. One limitation of 
case studies is that their results cannot be generalised since the present study was applied to specific companies in a specific context. Therefore, we have to stick only to the specific situations and not generalise. Another limitation is the interviewees' interpretation of the interview. The fact that the interview script used has technical terms that many times the interviewees may not understand or are even terms that they do not encounter daily makes it difficult for the interviewees to interpret the meaning, which may lead to a less adequate interpretation of the information and is usually not the information intended by the interviewers. Since the study was conducted during the COVID-19 pandemic, it made the whole process of conducting interviews with more companies difficult.

Although the objective of the present study is ambitious, its fulfillment may point to the need for a greater deepening of the themes under consideration. Issues such as disorders, vulnerabilities and resilience in supply chains can be studied in isolation and in greater depth. To this end, it is suggested that future studies should focus on each of these themes.

In future studies, we also suggest developing other lines of research, not only in a larger number of companies, for example, instead of analysing only SMEs, also analyse micro and large companies. It would be interesting to understand how many existing metrics different companies present to overcome a supply chain disruption. In this way, new metrics that some companies use are made known to other companies, which can support the good functioning of the supply chain within a company. Moreover, as a suggestion for future studies, it would be important to know the characteristics of supply chains, their connections from the point of view of vulnerabilities and the strength and direction of the environmental impact on their resilience. To conclude, we leave some research questions for future studies: Are SMEs able to have a formalised supply chain given their limited resources? What are the effects of supply chain metrics when applied to SMEs?

Author Contributions: Conceptualization, J.M.L.; methodology, C.F. and M.P. (Micaela Pestana); software, M.P. (Mariana Paiva); validation, C.F., C.C. and M.T.; formal analysis, J.M.L.; investigation, C.F., C.C., M.T., M.P. (Mariana Paiva) and M.P. (Micaela Pestana); writing-original draft preparation, J.M.L., C.F., C.C., M.T., M.P. (Mariana Paiva), M.P. (Micaela Pestana) and M.O.; writing-review and editing, M.O.; visualization, M.O.; supervision, J.M.L.; funding acquisition, J.M.L. and M.O. All authors have read and agreed to the published version of the manuscript.

Funding: This work was supported by the Foundation for Science and Technology “UIDB/04630/2020”. Institutional Review Board Statement: Not applicable.

Informed Consent Statement: Informed consent was obtained from all subjects involved in the study.

Acknowledgments: The authors would like to thank the Polytechnic Institute of Leiria, Miguel Torga Institute of Higher Education, University of Beira Interior, and NECE-Research Unit in Business Sciences, for their support.

Conflicts of Interest: The authors declare no conflict of interest.

\section{References}

1. Liu, J.; Tong, T.W.; Sinfield, J.V. Toward a resilient complex adaptive system view of business models. Long Range Plan. 2020, 54, 102030. [CrossRef]

2. Afuah, A.; Tucci, C. Internet Business Models and Strategies; McGraw-Hill: Boston, MA, USA, 2001.

3. Turner, J.R.; Baker, R.M. Complexity Theory: An Overview with Potential Applications for the Social Sciences. Systems $2019,7,4$. [CrossRef]

4. Karl, A.A.; Micheluzzi, J.; Leite, L.R.; Pereira, C.R. Supply chain resilience and key performance indicators: A systematic literature review. Production 2018, 28. [CrossRef]

5. Sureeyatanapas, P.; Waleekhajornlert, N.; Arunyanart, S.; Niyamosoth, T. Resilient supplier selection in electronic components procurement: An integration of evidence theory and rule-based transformation into TOPSIS to tackle uncertain and incomplete information. Symmetry 2020, 12, 1109. [CrossRef]

6. Mari, S.I.; Lee, Y.H.; Memon, M.S. Sustainable and resilient supply chain network design under disruption risks. Sustainability 2014, 6, 6666-6686. [CrossRef] 
7. Silva, R.M.D. Os impactos da pandemia do Covid-19 na cadeia de suprimentos e atividades logísticas: Contribuições e Insights Teóricos. INOVAE J. Eng. Archit. Technol. Innov. 2021, 9, 448-467.

8. Zhu, G.; Chou, M.C.; Tsai, C.W. Lessons Learned from the COVID-19 pandemic exposing the shortcomings of current supply chain operations: A long-term prescriptive offering. Sustainability 2020, 12, 5858. [CrossRef]

9. Pourhejazy, P.; Kwon, O.K.; Chang, Y.T.; Park, H. Evaluating resiliency of supply chain network: A data envelopment analysis approach. Sustainability 2017, 9, 255. [CrossRef]

10. Elleuch, H.; Dafaoui, E.; Elmhamedi, A.; Chabchoub, H. Resilience and Vulnerability in Supply Chain: Literature review. IFAC Pap. 2016, 49, 1448-1453. [CrossRef]

11. Alves, U.; Pereyron, L. A transferência vocálica em falantes bilíngues e trilíngues: Uma concepção de Língua como Sistema Adaptativo Complexo. REVEL Rev. Virtual Estud. Ling. 2016, 14, 226-265.

12. dos Santos, A.C.R.; De Held, M.S.B. Moda e a teoria da complexidade de Edgar Morin. Projetica 2018, 9, 55. [CrossRef]

13. Vieira, E.J.; Martins, H.C.; Gonçalves, C.A. Complexity Theory under the management perspective. Cad. UniFOA 2015, 10, 51-66. [CrossRef]

14. Guo, X.; Vogel, D.; Zhou, Z.; Zhang, X.; Chen, H. Chaos Theory as a Lens for Interpreting Blogging. J. Manag. Inf. Syst. 2009, 26, 101-128. [CrossRef]

15. Vieira, E.J.; Martins, H.C.; Gonçalves, C.A. Complexity theory: A study in organizations from several perspectives. Rev. Econ. Gestão 2014, 14, 85-112. [CrossRef]

16. Wang, C.; Dong, X.; Zhang, Y.; Luo, Y. Community resilience governance on public health crisis in china. Int. J. Environ. Res. Public Health 2021, 18, 2123. [CrossRef] [PubMed]

17. Fahimnia, B.; Sarkis, J.; Davarzani, H. Green supply chain management: A review and bibliometric analysis. Int. J. Prod. Econ. 2015, 162, 101-114. [CrossRef]

18. Sarkis, J.; Zhu, Q.; Lai, K.H. An organizational theoretic review of green supply chain management literature. Int. J. Prod. Econ. 2011, 130, 1-15. [CrossRef]

19. Amindoust, A. A resilient-sustainable based supplier selection model using a hybrid intelligent method. Comput. Ind. Eng. 2018, 126, 122-135. [CrossRef]

20. Sheffi, Y. Are You Prepared to Manage a Whack-A-Mole Recovery? Supply Chain Management Review. 2020. Available online: https:/ / medium.com/mitsupplychain/are-you-prepared-to-manage-a-whack-a-mole-recovery-6b79127ad63a (accessed on 15 June 2021).

21. Levary, R.R. Using the analytic hierarchy process to rank foreign suppliers based on supply risks. Comput. Ind. Eng. 2008, 55, 535-542. [CrossRef]

22. Shukla, A.; Lalit, V.A.; Venkatasubramanian, V. Optimizing efficiency-robustness trade-offs in supply chain design under uncertainty due to disruptions. Int. J. Phys. Distrib. Logist. Manag. 2011, 41, 623-646. [CrossRef]

23. Lim, M.K.; Bassamboo, A.; Chopra, S.; Daskin, M.S. Facility location decisions with random disruptions and imperfect estimation. Manuf. Serv. Oper. Manag. 2013, 15, 239-249. [CrossRef]

24. Blackhurst, J.; Rungtusanatham, M.J.; Scheibe, K.; Ambulkar, S. Supply chain vulnerability assessment: A network based visualization and clustering analysis approach. J. Purch. Supply Manag. 2018, 24, 21-30. [CrossRef]

25. Babich, V. Vulnerable options in supply chains: Effects of supplier competition. Nav. Res. Logist. 2006, 53, 656-673. [CrossRef]

26. Kim, Y.; Chen, Y.S.; Linderman, K. Supply network disruption and resilience: A network structural perspective. J. Oper. Manag. 2015, 33-34, 43-59. [CrossRef]

27. Treleven, M.; Bergman Schweikhart, S. A risk/benefit analysis of sourcing strategies: Single vs. multiple sourcing. J. Oper. Manag. 1988, 7, 93-114. [CrossRef]

28. Wagner, S.M.; Neshat, N. A comparison of supply chain vulnerability indices for different categories of firms. Int. J. Prod. Res. 2012, 50, 2877-2891. [CrossRef]

29. Crucitti, P.; Latora, V.; Marchiori, M.; Rapisarda, A. Error and attack tolerance of complex networks. Phys. A Stat. Mech. Its Appl. 2004, 340, 388-394. [CrossRef]

30. Wagner, S.M.; Bode, C. An empirical investigation into supply chain vulnerability. J. Purch. Supply Manag. 2006, 12, 301-312. [CrossRef]

31. Ponomarov, S.Y.; Holcomb, M.C. Understanding the concept of supply chain resilience. Int. J. Logist. Manag. 2009, 20, 124-143. [CrossRef]

32. Thomé, A.M.T.; Scavarda, L.F.; Scavarda, A.J. Conducting systematic literature review in operations management. Prod. Plan. Control 2016, 27, 408-420. [CrossRef]

33. Ali, A.; Mahfouz, A.; Arisha, A. Analysing supply chain resilience: Integrating the constructs in a concept. Supply Chain Manag. Int. J. 2017, 22, 1-49. [CrossRef]

34. Kamalahmadi, M.; Parast, M.M. A review of the literature on the principles of enterprise and supply chain resilience: Major findings and directions for future research. Int. J. Prod. Econ. 2016, 171, 116-133. [CrossRef]

35. CSM. Creating Resilient Supply Chains: A Practical Guide; Centre for Logistics and Supply Chain Management, Cranfield School of Management (CSM): West Yorkshire, UK, 2003.

36. Christopher, M.; Peck, H. Building the Resilient Supply Chain. Int. J. Logist. Manag. 2004, 15, 1-14. [CrossRef] 
37. Pettit, T.J.; Fiksel, J.; Croxton, K.L. Ensuring Supply Chain Resilience: Development of a Conceptual Framework. J. Bus. Logist. 2010, 31, 1-21. [CrossRef]

38. Pettit, T.J.; Croxton, K.L.; Fiksel, J. The Evolution of Resilience in Supply Chain Management: A Retrospective on Ensuring Supply Chain Resilience. J. Bus. Logist. 2019, 40, 56-65. [CrossRef]

39. Pettit, T.J.; Croxton, K.L.; Fiksel, J. Ensuring Supply Chain Resilience: Development and Implementation of an Assessment Tool. J. Bus. Logist. 2013, 34, 46-76. [CrossRef]

40. Scholten, K.; Scott, P.S.; Fynes, B. Mitigation processes-Antecedents for building supply chain resilience. Supply Chain Manag. 2014, 19, 211-228. [CrossRef]

41. Brusset, X.; Teller, C. Supply chain capabilities, risks, and resilience. Int. J. Prod. Econ. 2017, 184, 59-68. [CrossRef]

42. Giunipero, L.; Hohenstein, N.-O.; Feisel, E.; Hartmann, E. Research on the phenomenon of supply chain resilience. Int. J. Phys. Distrib. Logist. Manag. 2015, 45, 90-117.

43. Kamalahmadi, M.; Parast, M.M. An assessment of supply chain disruption mitigation strategies. Int. J. Prod. Econ. 2017, 184, 210-230. [CrossRef]

44. Pereira, C.R.; Christopher, M.; Lago Da Silva, A. Achieving supply chain resilience: The role of procurement. Supply Chain Manag. 2014, 19, 626-642. [CrossRef]

45. Christopher, M.; Holweg, M. Supply chain 2.0 revisited: A framework for managing volatility-induced risk in the supply chain. Int. J. Phys. Distrib. Logist. Manag. 2017, 47, 2-17. [CrossRef]

46. Melnyk, S.A.; Narasimhan, R.; DeCampos, H.A. Supply chain design: Issues, challenges, frameworks and solutions. Int. J. Prod. Res. 2014, 52, 1887-1896. [CrossRef]

47. Yaroson, E.V.; Breen, L.; Hou, J.; Sowter, J. Advancing the understanding of pharmaceutical supply chain resilience using complex adaptive system (CAS) theory. Supply Chain Manag. Int. J. 2021, 26, 323-340. [CrossRef]

48. Andersson, B.; Johannesson, P.; Zdravkovic, J. Aligning goals and services through goal and business modelling. Inf. Syst. e-Bus. Manag. 2009, 7, 143-169. [CrossRef]

49. Itami, H.; Nishino, K. Killing two birds with one stone: Profit for now and learning for the future. Long Range Plan. 2010, 43, 364-369. [CrossRef]

50. Baden-Fuller, C.; Haefliger, S. Business Models and Technological Innovation. Long Range Plan. 2013, 46, 419-426. [CrossRef]

51. Gassmann, O.; Frankenberger, K.; Sauer, R. Exploring the Field of Business Model. Innovation: New Theoretical Perspectives; Springer: Berlin/Heidelberg, Germany, 2016.

52. Hosseini, S.; Barker, K.; Ramirez-Marquez, J.E. A review of definitions and measures of system resilience. Reliab. Eng. Syst. Saf. 2016, 145, 47-61. [CrossRef]

53. Njie, B.; Asimiran, S. Case Study as a Choice in Qualitative Methodology. IOSR J. Res. Method Educ. 2014, 4, 35-40. [CrossRef]

54. Lopes, J.M.; Farinha, L.; Ferreira, J.J.; Ferreira, F. Peeking beyond the wall: Analysing university technology transfer and commercialisation processes. Int. J. Technol. Manag. 2018, 78, 107-132. [CrossRef]

55. Lopes, J.; Farinha, L.; Ferreira, J.J. Value creation and commercialization in insular ecosystems. Int. J. Soc. Ecol. Sustain. Dev. 2018, 9, 92-102. [CrossRef]

56. Yin, R. Case Study Research: Design and Methods; Sage Publications: Thousand Oaks, CA, USA, 2003.

57. Jüttner, U.; Peck, H.; Christopher, M. Supply chain risk management: Outlining an agenda for future research. Int. J. Logist. Res. Appl. 2003, 6, 197-210. [CrossRef]

58. Salimi, M.; Sampaio, P.; Golmaryami, S.S. Analyzing the implications of COVID-19 on supply chain quality management. In Proceedings of the 4th International Conference on Quality Engineering and Management, Braga, Portugal, 21-22 September 2020; pp. 221-232.

59. Moshood, T.D.; Nawanir, G.; Sorooshian, S. Digital Twins Driven Supply Chain Visibility within Logistics: A New Paradigm for Future Logistics. Appl. Syst. Innov. 2021, 4, 29. [CrossRef]

60. Tozanl1, Ö.; Kongar, E.; Gupta, S.M. Evaluation of waste electronic product trade-in strategies in predictive twin disassembly systems in the era of blockchain. Sustainability 2020, 12, 5416. [CrossRef]

61. Kuei, C.H.; Madu, C.N.; Lin, C. Developing global supply chain quality management systems. Int. J. Prod. Res. 2011, 49, 4457-4481. [CrossRef]

62. Ketchen, D.J., Jr.; Combs, J.G.; Russel, C.J.; Shook, C.; Dean, M.A.; Runge, J.; Lohrke, F.T.; Naumann, S.E.; Haptonstahl, D.E.; Baker, R.; et al. Organizational Configurations and Performance: A Meta-Analysis. Acad. Manag. J. 1997, 40, 223-240. [CrossRef]

63. Morcillo-bellido, J.; Isasi-sanchez, L.; Garcia-gutierrez, I.; Duran-heras, A. Model Based Analysis of Innovation in Sustainable Supply Chains. Sustainability 2021, 13, 4868. [CrossRef]

64. Hajej, Z.; Nyoungue, A.C.; Abubakar, A.S.; Ali, K.M. An Integrated Model of Production, Maintenance, and Quality Control with Statistical Process Control Chart of a Supply Chain. Appl. Sci. 2021, 11, 4192. [CrossRef]

65. Huang, S.; Potter, A.; Eyers, D. Using simulation to explore the influence of online reviews on supply chain dynamics. Comput. Ind. Eng. 2021, 151, 106925. [CrossRef]

66. Jacobs, M.A.; Yu, W.; Chavez, R. The effect of internal communication and employee satisfaction on supply chain integration. Int. J. Prod. Econ. 2016, 171, 60-70. [CrossRef]

67. Klueber, R.; O'Keefe, R.M. Defining and assessing requisite supply chain visibility in regulated industries. J. Enterp. Inf. Manag. 2013, 26, 295-315. [CrossRef] 
68. Hosoe, N. Impact of border barriers, returning migrants, and trade diversion in Brexit: Firm exit and loss of variety. Econ. Model. 2018, 69, 193-204. [CrossRef]

69. Motilewa, B.D. Survey data on supply chain improvement and operational competency of oil and gas firms in Nigeria. Data Brief 2018, 20, 1073-1078. [CrossRef] 